\title{
Pengembangan Modul Statistika Berbasis Software untuk Pembelajaran Jarak Jauh di Universitas Wahidiyah
}

\author{
Desi Gita Andriani *, Fajar Lestari \\ Universitas Wahidiyah, Kota Kediri, Indonesia \\ *Coresponding Author: desigitaandrianiuniwa@gmail.com
}

\begin{tabular}{ll}
\hline \hline Article history & Kesulitan mempelajari materi yang bersifat praktikum pada \\
Dikirim: & saat pembelajaran jarak jauh menyebabkan mahasiswa kurang \\
& paham dengan materi yang disampaikan, selain itu \\
Direvisi: & penyampaian materi yang hanya berupa slide persentasi saja, \\
30-12-2021 & mengakibatkan prestasi belajar statsitika mahasiswa rendah. \\
Diterima: & Sebagai upaya meningkatan prestasi belajar maka dibutuhkan \\
$31-12-2021$ & alat bantu berupa modul pembelajaran berbasis praktik, seperti \\
Kata kunci: & praktik penggunaan software statistik yang mampu \\
\hline modul statistika; & memudahkan dalam perhitungan statistika.Tujuan dari \\
software; pembelajaran & penelitian ini adalah untuk mengetahui pengembangan modul \\
jarak jauh & statistika berbasis software di Universitas Wahidiyah. Modul \\
& statistika berbasis software ini dikembangkan menggunakan \\
& model pengembangan 4-D yaitu Define, Design, Develop, dan \\
& Disseminate. Teknik pengumpulan data penelitian ini \\
& menggunakan angket yaitu angket validasi ahli dan angket respon \\
& mahasiswa terhadap penggunaan modul. Analisis yang digunakan \\
& penelitian ini menggunakan analisis statistik deskriptif yaitu \\
& dengan menghitung rata-rata dan persentase. Hasil penelitian ini \\
& menunjukkan bahwa modul statistika berbasis software valid dan \\
& layak digunakan sebagai modul pembelajaran jarak jauh mata \\
& kuliah statistika ditinjau dari aspek isi, bahasa, penyajian dan \\
& grafis.
\end{tabular}

\section{PENDAHULUAN}

Pesatnya perkembangan teknologi sekarang ini menuntut pembelajaran untuk mengikuti perkembangan zaman, karena dengan pemanfaatan teknologi sebagai media pembelajaran dapat memudahkan proses pembelajaran. Hal ini sependapat dengan Cucus \& Aprilianda (2016) yang mengungkapkan konsep pendidikan yang memanfaatkan teknologi informasi dalam proses belajar mampu mendukung jalannya pembelajaran. Begitupula dengan pembelajaran jarak jauh yang menggabungkan prinsip-prinsip pembelajaran dengan pemanfaatan teknologi serta sistem pembelajaran yang dipakai untuk proses belajar mengajar dilaksanakan tanpa harus bertatap muka secara langsung antara pendidik dengan peserta didik (Chandrawati, 2010). Pembelajaran jarak jauh sekarang ini semakin marak digunakan akibat dari penutupan sekolah maupun universitas dapak pandemi Covid 19.

Hal paling utama yang mendasari keberhasilan proses pembelajaran jarak jauh selain tersedianya sarana yang mendukung seperti internet maupun HP atau leptop, konten interaksi antar pengguna juga sangat di butuhkan sebagai pengganti proses tatap muka (Nugroho, 2012; Syarifuddin dkk, 2021). Namun 
kebanyakan bahan ajar yang digunakan untuk proses pembelajaran tersaji dalam dalam bentuk text atau slide presentasi. Konten text atau slide presentasi dirasa masih kurang dalam memenuhi kebutuhan belajar, karena sangat minimal interaksi sehingga beberapa pelajaran khususnya yang bersifat praktikum akan lebih sulit di sampaikan, seperti pembelajaran statistika. Materi statistika sangat erat kaitanya dengan hitungan, materi ini sangat menunjang tugas akhir mahasiswa diberbagai bidang.

Berdasarkan hasil observasi ditemumukan fakta mahasiswa Universitas Wahidiyah mengalami kesulitan mempelajari materi yang bersifat praktikum pada saat pembelajaran jarak jauh. Berdasarkan hasil wawancara beberapa mahasiswa mengungkapkan bahwa penyampaian materi pembelajaran jarak jauh yang tidak sedetail saat tatap muka menyebabkan mereka kurang paham dengan materi yang disampaikan, selain itu penyampaian materi hanya berupa slide persentasi saja, akibatnya prestasi belajar statsitika mahasiswa rendah. Sebagai upaya meningkatan prestasi belajar maka dibutuhkan alat bantu berupa modul pembelajaran berbasis praktik, seperti praktik penggunaan software statistik yang mampu memudahkan dalam perhitungan statistika. Hal ini dikarenakan modul pembelajaran merupakan bahan ajar yang mempunyai karakteristik belajar mandiri.

Menurut Rufii (2015) modul pembelajaran merupakan pengalaman pembelajaran yang terstruktur secara mandiri dengan serangkaian kriteria pembelajaran yan jelas dan koheren serta memiliki kriteria penilaian yang jelas. Kelebihan pembelajaran menggunakan modul menurut Lasmiyati \& Harta (2014) yaitu (a) modul memberikan umpan balik sehingga mahasiswa dapat segera melakukan perbaikan, (b) modul menetapkan tujuan pembelajaran yang jelas sehingga aktifitas belajar mahasiswa lebih terarah dalam mencapai tujuan pembelajaran, (c) modul memiliki desain yang menarik dan mudah dipelajari sehingga dapat meningkatkan motivasi belajar mahasiswa, (d) modul bersifat fleksibel karena materi yang dipelajari antar mahasiswa bisa berbeda tergantung kecepatan mahasiswa mempelajari tiap materi, (e) modul meminimalisir persaingan antar mahasiswa sehingga kerjasama lebih terjalin, (f) modul memberikan kesempatan mahasiswa untuk dapat menemukan sendiri kelemahannya berdasarkan evaluasi yang diberikan. Tujuan dari penelitian ini adalah untuk mengetahui pengembangan modul statistika berbasis software di Universitas Wahidiyah.

\section{KAJIAN TEORI}

\section{Modul Pembelajaran}

Modul adalah salah satu bahan ajar yang memiliki karakteristik prinsip belajara mandiri. Menurut Lestari \& Andriani (2019) modul merupakan suatu bahan ajar yang dibuat secara singkat dan spesifik untuk mencapai tujuan pembelajaran. Biasanya dalam modul materi maupun evaluasi terkoordinir dengan baik, sehingga mudah untuk dipahami. Modul adalah suatu bahan ajar yang dipilih sebagai usaha pengembangan pembelajaran yang lebih efisien, relavan, dan efektif (Mahadiraja \& Syamsuarnis, 2020).

Lestari \& Andriani (2019) menyatakan bahwa kualitas modul dilihat dari aspek berikut. 
a. Aspek kelayakan isi, meliputi materi modul sesuai dengan kompetensi yang diharapkan, modul sesuai dengan keperluan materi yang diajarkan, modul berisi materi pelajaran yang benar, modul memiliki kebermanfaatan untuk menambah wawasan, modul sesuai dengan nilai moral dan sosial.

b. Aspek kelayakan bahasa, meliputi keterbacaan, kejelasan informasi, modul mengikuti aturan penulisan bahasa Indonesia yang baik dan benar, modul menggunakan kalimat yang efektif dan efisien.

c. Aspek kelayakan penyajian, meliputi modul menjelaskan ketercapaian tujuan yang diinginkan secara rinci, modul menyajikan materi secara runtut, modul mengandung kalimat motivasi, modul memiliki daya tarik, interaksi, dan kelengkapan informasi.

d. Aspek kelayakan kegrafisan, meliputi penggunaan font huruf, lay out, ilustrasi, gambar, foto, dan desain tampilan.

Begitu pula dengan modul pembelajaran ini digunakan untuk melakukan pembelajaran jarak jauh, sehingga mahasiswa dapat belajar secara mandiri, karena tidak adanya tatap muka secara langsung antara dosen dengan mahasiswa.

\section{Software Statistika}

Statistika merupakan salah satu materi yang dapat diterapkan diberbagai bidang ilmu (Fitri, 2011). Menurut Agusyana \& Islandscript (2011) statistik yang berarti sekumpulan data yang melukiskan atau menggambarkan sebuah persoalan. Sedangkan menurut Syafriandi, Amalita \& Kurniawati (2018), statistika adalah bidang ilmu yang mempelajari tentang cara mengumpulkan, mengolah, menganalisis dan menginterpretasikan suatu data.

Statistik dalam konteks keilmuan tidak hanya berarti data angka saja, karena ilmu statistik lebih dari sekedar sekumpulan data mentah. Statistik juga dipakai untuk melakukan berbagai kegiatan analisis terhadap data seperti membuat grafik, menampilkan data dalam bentuk tabel, melakukan peramalan (forecasting), melakukan berbagai uji hipotesis dan kegunaan lainya. Pengolahan data statistik dapat dilakukan secara manual maupun komputasi. Pengolahan data secara manual maupun komputasi dapat dilakukan baik terhadap data sedikit maupun banyak. Namun dalam praktiknya pengolahan data data secara manual penuh dengan operasi matematika mulai dari yang sederhana sapai pada yang rumit. Sehingga pengolahan data secara manual hanya dapat dilakukan dengan data sedikit, sedangkan untuk data yang banyak akan mengalami kendala waktu dan biaya, sehingga kurang efektif dan efisien.

Berbeda dengan pengolahan data secara komputasi yang mana dalam pengolahannya menggunakan perangkat lunak atau software. Hasil pengolahan data dengan software jauh lebih akurat bila dibandingkan dengan pengolahan data dengan manual. Menurut Agusyana \& Islandscript (2011) software statistik terdiri atas software yang melakukan pekerjaan perhitungan angka dari data statistik yang akan diolah. Secara alur program software statistik sebenarnya menjalankan rumus yang berlaku dan sesuai dengan kebutuhan dalam pengorasiannya. Menurut Santoso (2011) software statistik merupakan suatu program komputer yang sangat berperan dalam kegiatan pengolahan data statsistik. Semakin pesatnya perkembangkan teknologi saat ini banyak software statistika yang dapat digunakan dalam pengolahan data, seperti: Microsoft Excel, SPSS, Minitep, Amos, SEM, PLS, dll. Dengan demikian dapat disimpulkan 
bahwa software statistika adalah suatu program komputer tentang statistik yang dapat digunakan dalam kegiatan pengolahan data statsistik.

\section{METODE PENELITIAN}

Jenis penelitian ini merupakan jenis Research and Development (R \& D). R \& $\mathrm{D}$ dipilih karena bertujuan untuk menghasilkan produk baru melalui proses pengembangan (Sugiyono, 2017). Penelitian ini menggunakan model pengembangan 4-D. Lebih lengkap prosedur pengembangan 4-D (Santia dan Jatmiko, 2016) adalah sebagai berikut:

1. Define (Pendefinisisan)

Pada tahap ini peneliti melakukan penetapan dan pendefinisian syaratsyarat pembelajaran. Ada lima langkah pada tahap ini yaitu front end analisis, learner analysis, task analysis, concept analysis dan Specifying Instructional Objective.

2. Design (Perancangan)

Pada tahap ini produk yang dirancang adalah modul statistika berbasis software. Modul dikembangkan berdasarkan materi yang sesuai dengan RPS, tujuan mata kuliah, penggunaan software dan evaluasi yang terstruktur pada mata kuliah statistika.

3. Pengembangan (Development)

Pada tahap ini modul yang dikembangkan harus memenuhi kriteria kevalidan. Validasi yang digunakan adalah validasi ahli. Validasi ahli terdiri dari validasi ahli materi, ahli grafis dan ahli bahasa. Untuk mengetahui kevalidan modul maka dihitung rata-rata penilaian dari semua validator. Hasil perihungan rata-rata diitepretasikan ke dalam kategori sebagai berikut:

Tabel 1. Intepretasi Skor Kevalidan

\begin{tabular}{cc}
\hline Penilaian & Kriteria Kevalidan \\
\hline $1.00 \leq \mathrm{x}<2.00$ & Tidak Valid \\
\hline $2.00 \leq \mathrm{x}<3.00$ & Kurang Valid \\
\hline $3.00 \leq \mathrm{x}<4.00$ & Valid \\
\hline $4.00 \leq \mathrm{x}<5.00$ & Sangat Valid \\
\hline Sumber : Santia \& Jatmiko (2016) &
\end{tabular}

4. Penyebaran (Desseminate)

Pada tahap ini penyebaran modul pembelajaran dilakukan dalam bentuk softcopy. Penyebaran modul pembelajaran dilakukan sebagai uji coba lapangan yang bertujuan untuk mengetahui kelayakan modul terhadap pembelajaran statsitika. Uji coba lapangan dilakukan dengan uji coba terbatas yaitu pada saat pembelajaran statistika di Universitas Wahidiyah. Penilaian kelayakan dilakukan dengan menggunakan angket. Menurut Riduwan (2013), metode angket adalah cara pengumpulan data melalui daftar pertanyaan yang diberikan kepada orang lain yang bersedia memberikan respon.

Angket yang dimaksud penelitian ini adalah angket respon mahasiswa terhadap penggunaan modul. Angket penggunaan modul disusun untuk melihat kelayakan modul. Untuk mengetahui kelayakan penggunaan modul, maka dari hasil angket kemudian dihitung dengan rumus persentase. Hasil perhitungan persentase diitepretasikan ke dalam kategori sebagai berikut: 
Tabel 2. Intepretasi Skor Kelayakan Modul

\begin{tabular}{cc}
\hline Penilaian & Kriteria Kelayakan \\
\hline $0 \%-20 \%$ & Sangat Tidak Layak \\
\hline $21 \%-40 \%$ & Tidak Layak \\
\hline $41 \%-60 \%$ & Cukup Layak \\
\hline $61 \%-80 \%$ & Layak \\
\hline $81 \%-100 \%$ & Sangat Layak
\end{tabular}

Sumber : Santia, Fiantika \& Jatmiko (2017)

Menurut Santia, Fiantika \& Jatmiko (2017), modul dikatakan layak apabila persentase $\geq 61 \%$.

\section{HASIL DAN PEMBAHASAN}

Tahap pertama define (pendefinisian), ada lima tahap pada tahap ini yaitu (1) front end analisis (analisis awal dan akhir) untuk mengetahui masalah dasar yang dihadapai dalam pembelajaran sehingga dibutuhkan pengembahan modul statistika berbasis software. Berdasarkan analisis ditemukan masalah mahasiswa mengalami kesulitan mempelajari materi yang bersifat praktikum pada saat pembelajaran jarak jauh. (2) Learner analysis (analisis siswa) untuk mengetahui karakteristik subyek (mahasiswa) sebagai gambaran dalam merancang modul stasistika. (3) Task analysis (analisis tugas) digunakan untuk mengidentifikasi tugas atau latihan yang terdapat pada modul statistika. (4) Concept analysis (analisis konsep) dapat dilakukan dengan membuat peta konsep materi pada modul statistika. (5) Specifying Instructional Objective (spesifikasi tujuan pembelajaran) yaitu untuk mengembangkan kemampuan mahasiswa khususnya dalam praktikum analisis data.

Tahap ke dua design (perancangan), secara garis besar tahap ini dilakukan dengan dua langkah yaitu (1) pemilihan format modul, mulai dari format sampul dan sampul belakang modul statistika, format struktur isi modul statistika meliputi materi yang sesuai dengan RPS, tujuan mata kuliah statistika, penggunaan software dan evaluasi yang terstruktur pada mata kuliah statistika (2) desain awal modul, dirancang sedemikian rupa agar modul statsitika lebih menarik dan memotivasi mahasiswa untuk dapat belajar secara mandiri.

Tahap ke tiga develop (pengembangan), pada tahap ini modul yang dikembangkan harus memenuhi kriteria kevalidan, sehingga dilakukan uji validitas modul statsitika oleh ahli materi, ahli grafis dan ahli bahasa. Ahli materi modul statistika ini adalah satu dosen Prodi Pendidikan Matematika dengan bidang keahlian pendidikan matematika di Universitas Nusantara PGRI Kediri. Ahli grafis adalah orang yang berkompeten pada bidang kegrafisan, karena modul statistika yang dikembangakan berbasis software, sehingga ahli grafis modul ini adalah satu dosen Fakultas Teknik di Universitas Wahidiyah. Ahli bahasa modul ini adalah satu dosen Prodi Bahasa dan Sastra Indonesia di Universitas Nusantara PGRI Kediri. Adapun hasil analisis validasi ketiga ahli adalah sebagai berikut: 
Tabel 3. Hasil Uji Validasi Modul

\begin{tabular}{clcc}
\hline No & Ahli/Validator & Penilaian Kevalidan & Kriteria Kevalidan \\
\hline 1 & Materi & 4.07 & Sangat Valid \\
\hline 2 & Grafis & 3.80 & Valid \\
\hline 3 & Bahasa & 3.87 & Valid \\
\hline
\end{tabular}

Berdasarkan Tabel 3 dapat diketahui bahwa hasil uji validasi ahli materi sebesar 4,07 masuk kategori sangat valid, hal ini berarti dari aspek isi modul statistika sudah sangat sesuai dengan RPS, tujuan mata kuliah statistika, penggunaan software dan evaluasi yang terstruktur pada mata kuliah statistika. Sedangkan pada hasil uji validasi ahli grafis sebesar 3,80 masuk kategori valid, ini berarti dari aspek grafis atau penyajian isi, layout struktur isi dapat dikatakan sudah sesuai dengan isi materi statistika dan dapat menarik serta memotivasi mahasiswa untuk belajar mandiri. Pada hasil uji validasi ahli bahasa diperoleh hasil 3,87 masuk kategori valid, yang artinya bahasa yang digunakan pada modul statistika sudah sesuai dengan aturan EYD yang berlaku dan sesuai dengan karakteristik subyek sehingga bahasa yang digunakan mudah untuk dipahami.

Pada tahap validasi ini selain memberikan penilaian validator juga memberikan masukan untuk melakukan perbaikan. Pada ahli materi memberikan masukan terkait: penambahan contoh latihan soal dan pembetulan penulisan yang masih ada beberapa yang tipo. Pada ahli grafis memberikan masukan tentang: gambar dibuat lebih seimbang, dan warna sampul depan dibuat lebih menarik lagi. Dari masukan validator tersebut peneliti melakukan resivi terhadap modul yang dikembangkan.

Tahap ke empat desseminate (penyebaran), pada tahap ini dilakukan penyebaran modul statistika sebagai uji coba lapangan yang bertujuan untuk mengetahui kelayakan modul yang dikembangkan terhadap pembelajaran statsitika. Angket respon terbagi menjadi empat aspek yaitu kelayakan isi, kelayakan bahasa, kelayakan penyajian dan kelayakan grafis. Berikut adalah hasil analisis angket respon mahasiswa terhadap penggunaan modul.

Tabel 4. Hasil Analisis Angket Respon Uji Coba Terbatas

\begin{tabular}{clcc}
\hline No & Aspek Kelayakan & $(\%)$ & Kriteria Kelayakan \\
\hline 1 & $\begin{array}{l}\text { Kelayakan Isi: } \\
\text { a. Kesesuaian dengan RPS } \\
\text { b. Keseuaian dengan } \\
\text { software }\end{array}$ & $81 \%$ & Sangat Layak \\
\hline 2 & Kelayakan Bahasa & $82 \%$ & Sangat Layak \\
\hline 3 & Kelayakan Penyajian & $76 \%$ & Layak \\
\hline 4 & Kelayakan Kegrafisan & $78 \%$ & Layak \\
\hline
\end{tabular}

Berdasarkan Tabel 4 diketahui bahwa kelayakan isi modul statistika berbasis software yang dikembangkan baik dari aspek kesekuain isi dengan materi di RPS maupun kesesuain isi dengan software yang digunakan sangatlah layak. Sedangkan Pada aspek kelayakan bahasa berdasarkan analisis respon mahasiswa menunjukkan modul statistika berbasis software yang dikembangkan layak karena keterbacaan, kejelasan informasi, bahasa mengikuti aturan penulisan bahasa Indonesia yang baik dan benar, serta menggunakan kalimat yang efektif dan efisien. 
Pada aspek kelayakan penyajian berdasarkan analisis respon mahasiswa menunjukkan bahwa modul statistika berbasis software yang dikembangkan layak karena modul menjelaskan ketercapaian tujuan yang diinginkan secara rinci, menyajikan materi secara runtut, mengandung kalimat motivasi, memiliki daya tarik, interaksi, dan kelengkapan informasi. Sedangkan pada aspek kelayakan kegrafisan menunjukkan bahwa modul statistika berbasis software yang dikembangkan layak karena penggunaan font huruf, lay out, ilustrasi, gambar, foto, dan desain tampilan modul sesuai dan menarik.

\section{KESIMPULAN}

Berdasarkan hasil dan pembahasan pengembangan modul statistika berbasis software dapat disimpulkan bahwa modul tersebut valid dan layak digunakan sebagai modul pembelajaran jarak jauh mata kuliah statistika ditinjau dari aspek isi, bahasa, penyajian dan grafis. Berdasarkan hasil yang diperoleh dapat disarankan perlu untuk dilakukan pengujian efektifitas penggunaan modul terhadap peningkatan hasil belajar mahasiswa.

\section{UCAPAN TERIMA KASIH}

Ucapan terimakasih penulis sampaikan kepada bapak dan ibu validator yang bersedia memberikan penilaian validasi terhadap modul yang dikembangakan.

\section{DAFTAR PUSTAKA}

Agusyana, Y. \& Islandscript. (2011). Olah Data Skripsi dan Penelitian dengan SPSS 19. Jakarta : PT. Elex Media Komputindo.

Chandrawati, S.R. (2010). Pemanfaatan Elearning dalam Pembelajaran. Jurnal Cakrawala Kependidikan. 2(8): 172 - 181.

Cucus, A. \& Aprilinda, Y. (2016). Pengembangan E-Learning Berbasis Multimedia Untuk Efektivitas Pembelajaran Jarak. Explore-Jurnal Sistem Informasi dan Telematika. 7(1): $1-5$.

Lasmiyati \& Harta, I. (2014). Pengembangan Modul Pembelajaran untuk Meningkatkan Pemahaman Konsep dan Minat SMP. PYTHAGORAS: Jurnal Pendidikan Matematika 9(2): 161-174.

Lestari, F., \& Andriani, D. (2019). Analisis Uji Coba Terbatas Pada Pengembangan Modul Statistika Matematika Berbasis Literasi. Prosiding Sendika, 5(1): 658661.

Lestari, F., \& Andriani, D. (2019). Validasi modul berbasis literasi pada mata kuliah statistika matematika. Jurnal Math Educator Nusantara: Wahana Publikasi Karya Tulis Ilmiah Di Bidang Pendidikan Matematika, 5(1): 36-42.

Mahadiraja, D. \& Syamsuarnis. (2020). Pengembangan Modul Pembelajaran Berbasis Daring pada Mata Pelajaran Instalasi Penerangan Listrik Kelas XI 
Teknik Instalasi Tenaga Listrik T.P 2019/2020 di SMK Negeri 1 Pariaman. JTEV (Jurnal Teknik Elektro Dan Vokasional). 6(1): 77-82.

Nugroho, A. 2012. Pengembangan Model Pembelajaran Jarak Jauh Berbasis Web (Model Development of Web-based Distance Learning). Jurnal Transformatika, 9(2): $72-78$.

Riduwan (2013). Dasar-dasar Statistika. Bandung : Alfabeta.

Rufii. (2015). "Developing Module on Construktivist Learning Stategies to Promote Students' Independence and Performance". International Journal of Education. 7(1): 18-28.

Santia, I. \& Jatmiko. (2016). Pengembangan Modul Pembelajaran Matematika Berdasarkan Proses Berpikir Relasional Dalam Upaya Meningkatkan Kemampuan Menyelesaikan Masalah Aljabar Siswa SMP. Jurnal Math Educator Nusantara: Wahana Publikasi Karya Tulis Ilmiah Di Bidang Pendidikan Matematika, 3(2): 127-134.

Santia, I., Fiantika, F., \& Jatmiko, J. (2017). Pengembangan BKS Berbasis Mck (Mathematical Content Knowledge) Sebagai Upaya Meningkatkan Literasi Matematika Siswa SMP. Jurnal Math Educator Nusantara: Wahana Publikasi Karya Tulis Ilmiah Di Bidang Pendidikan Matematika, 3(2): 127-134.

Santoso, S. (2011). Matering SPSS Versi 19. Jakarta : PT. Elex Media Komputindo.

Sugiyono. (2017). Metode Penelitian Kuantitatif, Kualitatif, dan R\&D. Bandung: Alfabeta.

Syafriandi, Amalita, N. \& Kurniawati,Y. (2018). Upaya Peningkatan Kemampuan Analisis Data Penelitian Menggunakan Software Statistik Bagi Guru-Guru Matematika SMA Kabupaten Pesisir Selatan. Jurnal Eksakta Pendidikan (JEP). 2(1): $1-8$.

Syarifuddin, S., Nugroho, P. B., Fadhli, M., Murtalib, M., Mutmainah, M., Muchlis, M., ... \& Hadi, A. M. (2021). Sosialisasi Aplikasi Pembelajaran Jarak Jauh dan Pengembangan Bahan Ajar bagi Dosen, Guru, dan Mahasiswa di Era Pandemi Covid-19. Bima Abdi: Jurnal Pengabdian Masyarakat, 1(1), 30-36. 